\title{
TERAPI SULIH (SWITCH THERAPY) ANTIBIOTIK PADA PASIEN PNEUMONIA KOMUNITI DI RSUD WANGAYA KOTA DENPASAR
}

\author{
Dewi Puspita Apsari*, Ni Made Krisna Dwiyanti, I.B.N. Maharjana \\ Program Studi Farmasi Klinis, Fakultas Ilmu-Ilmu Kesehatan, Universitas Bali \\ Internasional \\ *: dewipuspitaapsari@gmail.com
}

\begin{abstract}
ABSTRAK
Pasien pneumonia komuniti yang dirawat inap selalu diresepkan antibiotik intravena (IV). Penggunaan antibiotika IV yang tidak tepat akan mengakibatkan peningkatan beban biaya pengobatan dan resistensi antibiotika. Terapi sulih (switch theraphy) antibiotika dari IV ke oral dapat digunakan untuk mengatasi masalah tersebut. Tujuan dari penelitian ini adalah untuk menilai praktik terapi sulih dari pasien pneumonia komuniti. Penelitian observasional dengan desain retrokspektif ini dilakukan dengan mengambil data rekam medik pasien selama periode Januari-Desember 2019. Data yang diambil mencakup data karakteristik pasien, pola penggunaan antibiotika dan pola penggantian antibiotika dari IV ke oral. Pasien dewasa yang menjalankan terapi sulih diikutkan dalam penelitian ini. Data dianalisis secara deskriptif dengan menggunakan SPSS 17.0. Hasil penelitian menunjukkan sebanyak 78 pasien mendapatkan terapi sulih. Lama waktu penggantian IV ke oral. Sebanyak 55(70,5\%) pasien yang diteliti mengalami waktu penggantian antibiotik dalam 48-72 jam sejak dirawat inap. Golongan beta laktam merupakan golongan yang paling banyak digunakan untuk melakukan terapi sulih. Pola penggantian step-down merupakan pola yang paling banyak digunakan dengan angka $48(61,5 \%)$ dilanjutkan dengan sequential dan switch over dengan angka 21 (27\%) dan 9 (11,5\%) secara berturut-turut. Penelitian ini menemukan bahwa RSUD Wangaya untuk lebih meningkatkan praktik pola penggantian sequential demi menurunkan beban biaya pengobatan pneumonia komuniti.
\end{abstract}

Kata Kunci : Pneumonia Komuniti, Sulih Terapi, Sequential, Switch Over, StepDown

\section{ABSTRACT}

Hospitalized community-acquired pneumonia (CAP) patients are always prescribed intravenous (IV) antibiotics. Inappropriate and unnecessary IV antibiotics usage leads to an increase in healthcare costs and bacterial resistance. IV to per oral (PO) conversion therapy can overcome these problems. The aim of the study was to evaluate the practice of switching from intravenous to oral antibiotics of inpatients with community-acquired pneumonia (CAP). This retrospective observational study was conducted by taking patient medical record from january until december 2019. Outcomes of the study are patient characteristics, pattern use, antibiotic and type conversion therapy. Adult inpatients on conversion therapy were eligible for study enrollment. Data were analyzed descriptively using SPSS 17.0. The study showed that among 78 patients who were eligible for conversion therapy. Most of the patient has mean 
duration conversion therapy 48-72 hours as much as 55 (70,5\%). Beta-lactams were the most commonly converted antibiotics. However, the step-down therapy was the major type of conversion practiced in this study as much as $48(61,5)$ followed by sequential and switch over with numbers 21 (27\%) and 9 (11,5\%) respectively. Based on the study findings wangaya hospital should improve the practice of sequential therapy in order to reduce the burden of CAP.

Keywords : Community-Acquired Pneumonia (CAP), Conversion Therapy, Sequential, Switch Over, Step-Down

\section{PENDAHULUAN}

Pneumonia komuniti merupakan salah satu infeksi akut tersering yang memerlukan perawatan di rumah sakit $^{1}$. Di Indonesia, setiap 100.000 pasien yang keluar dari rumah sakit, terdapat 988 kasus pneumonia komuniti. Dampak dari penyakit ini antara lain mengakibatkan morbiditas, mortalitas dan biaya rawat inap yang tidak sedikit. Biaya rawat inap yang dikeluarkan pasien pneumonia komuniti mencapai USD 254-1.208 ${ }^{2}$. Sebanyak 5\% pasien pneumonia komuniti yang dirawat inap memerlukan perawatan intensif di ICU dan penyakit ini mengakibatkan mortalitas hingga mencapai $35 \%^{3}$. Salah satu cara yang dapat ditempuh untuk meminimalkan dampak dari pneumonia komuniti adalah dengan mengoptimalkan penggunaan antibiotika ${ }^{4}$.

Bakteri patogen penyebab pneumonia komuniti antara lain streptococcus pneumoniae dan moraxella catarrhalis. Bakteri tersebut bertanggung jawab atas $85 \%$ kasus pneumonia komuniti ${ }^{5}$. Antibiotika dengan spektrum yang tepat dapat digunakan untuk membunuh bakteri tersebut. Pasien pneumonia komuniti yang dirawat inap selalu diberikan antibiotika dalam bentuk intravena (IV) ${ }^{6}$. Tujuan pemberian antibiotika dalam bentuk intravena (IV) adalah untuk mendapatkan konsentrasi antibotika yang optimal pada lokasi infeksi. Antibiotika IV yang diberikan harus dilakukan secara rasional. Tidak rasionalnya terapi antibiotika yang diberikan akan mengakibatkan resistensi bakteri dan peningkatan biaya pengobatan ${ }^{7}$. Terapi sulih (switch theraphy) antibiotika dari IV ke oral merupakan salah satu cara untuk meningkatkan rasionalitas pengobatan pada pneumonia komuniti. Keuntungan yang 
didapatkan dengan dilakukanya terapi sulih yakni tingginya angka kesembuhan klinis, menurunkan biaya pengobatan dan lama waktu rawat inap di rumah sakit ${ }^{8}$. Selain itu juga terapi sulih dapat menurunkan kejadian phleibitis dan infeksi akibat penggunaan $\mathrm{IV}^{5}$. Walaupun terapi sulih memiliki keuntungan, akan tetapi praktik terapi sulih ini tidak sepenuhnya dilakukan di lapangan.

Terdapat beberapa kendala tidak dilakukannya terapi sulih yakni kurangnya rekomendasi pedoman yang jelas dan kecilnya harapan klinisi terkait keuntungan terapi sulih $^{6}$. Schouten et al., (2007) menyebutkan bahwa tingkat kepatuhan tenaga kesehatan untuk melakukan terapi sulih sesuai pedoman terapi pada pneumonia komuniti adalah 58\%. Angka tersebut juga bervariasi pada rumah sakit yang berbeda yakni $22-94 \%$.

Mayoritas pasien tanpa gejala yang berat dapat dilakukan terapi sulih pada hari ke 2-4 pengobatan. Terapi sulih dapat dilakukan jika pasien menunjukkan perbaikan pada gejala saluran pernapasan, tidak ada panas dalam waktu kurang lebih 8 jam, nilai sel darah putih telah normal dan adekuat untuk makan secara oral $^{8}$. Terapi sulih dibagi menjadi tiga yakni switch therapy, sequential therapy dan step-down therapy. Saat melakukan terapi sulih klinisi akan mengubah penggunaan antibiotika yang semula IV menjadi oral. Selain itu juga penggantian dilakukan dengan komponen antibiotika yang sama atau berbeda. Hal ini harus dilakukan secepatnya agar antibiotika tidak kehilangan potensinya. Sejak tahun 1990 , terapi sulih ini telah banyak dilakukan oleh berbagai macam negara. Sejak saat itu banyak penelitian yang diperlukan untuk membuktikan efikasi, keamanan dan biaya yang dikeluarkan jika terapi sulih dilakukan? ${ }^{7}$.

Rencana, pelaksanaan dan evaluasi terapi sulih memiliki beberapa karakteristik untuk mencapai terapi yang ideal. Formulasi dari bentuk sediaan oral harus ditoleransi dengan baik bila diberikan secara oral dan juga memiliki bioavailabilitas yang baik (lebih dari 80\%). Selain itu juga sediaan oral harus tersedia dalam 
berbagai bentuk sediaan (tablet, kapsul dan cair) dan frekuensi dosis yang diberikan ekuivalen dengan antibiotika IV yang sebelumnya diberikan. Identifikasi yang tepat dari diagnosis pasien, pengobatan dan kontraindikasi terhadap terapi sulih merupakan aspek penting untuk keberhasilan terapi ini ${ }^{10}$.

Pasien yang melakukan terapi sulih akan dieksklusi jika mengalami kerusakan saluran pencernaan, perdarahan aktif pada saluran pencernaan,kejang,hipotensi atau shock dan sedang berada di ICU. Selain itu juga pasien yang menolak obat oral, pasien dengan kelainan sistem imun dan pasien dengan infeksi yang berat juga harus dieksklusi dari terapi sulih ${ }^{11,12,13}$. Oleh karena itu tujuan dari penelitian ini adalah untuk menilai praktik terapi sulih dari pasien rawat inap yang mengalami pneumonia komuniti di RSUD Wangaya Denpasar. Hasil dari penelitian ini diharapkan dapat memberikan rekomendasi kepada rumah sakit mengenai penggunaan antibiotika yang rasional pada kasus pneumonia komuniti. Sehingga kedepannya rumah sakit dapat menurunkan beban biaya pengobatan pneumonia komuniti.

\section{METODE PENELITIAN}

Penelitian ini termasuk kedalam penelitian observasional dengan desain penelitian deskriptif. Data penelitian diambil dari rekam medik pasien selama tahun 2019. Data yang diambil mencakup data karakteristik pasien, pola penggunaan antibiotika dan pola penggantian antibiotika dari IV ke oral. Data karakteristik pasien diantaranya usia, jenis kelamin, penyakit penyerta, lama rawat inap dan gejala klinis yang dialami pasien. Pola penggunaan antibiotika tersebut mencakup golongan antibiotika yang digunakan pasien. Pola penggantian dari IV ke oral diantaranya waktu penggantian dan pola penggantian (switch therapy, sequential therapy dan step-down therapy).

Subjek dalam penelitian ini adalah pasien rawat inap yang didiagnosa mengalami pneumonia komuniti dan berusia lebih dari 18 tahun. Selain itu juga pasien telah mendapatkan sulih terapi dari IV ke 
oral. Sedangkan subjek yang dieksklusi pada penelitian adalah pasien dengan rekam medik yang tidak lengkap, pasien dengan kelainan sistem imun (contohnya seperti HIV/AIDS dan kanker stadium akhir), pasien terminal yang sudah tidak ada harapan sembuh, pasien yang sebelumnya dirawat di ICU, pasien dengan riwayat cyctic fibrosis dan pasien dengan penyakit infeksi lainnya. Rumus slovin digunakan dalam menghitung jumlah sampel yang dibutuhkan. Sehingga total sampel yang dibutuhkan adalah 78 orang. Teknik pengambilan sampel yang digunakan adalah purposive sampling. Data yang didapat kemudian dianalisis secara deskriptif dengan menggunakan SPSS 17.0

\section{HASIL DAN PEMBAHASAN}

Mayoritas 78 responden yang diteliti berusia kurang dari 60 tahun sebanyak $43(55,1 \%)$ dan berjenis kelamin laki-laki sebanyak 57 $(73,1 \%)$ sesuai dengan Tabel 1. Pasien yang mengalami pneumonia komuniti paling banyak dirawat inap selama 4-7 hari sebesar 56 $(71,8 \%)$. Hasil yang didapat sesuai dengan penelitian Menéndez et al. (2001), yakni lama rawat inap pasien yang mengalami infeksi bakteri adalah 7-10 hari. Lama rawat inap pasien dirumah sakit juga sangat dipengaruhi oleh penyakit penyerta yang dimiliki oleh pasien. Ketidakstabilan penyakit penyerta yang dimiliki oleh pasien pneumonia komuniti akan memperpanjang lama rawat inap $^{14}$.

Tabel 1. Karakteristik Pasien

\begin{tabular}{|c|c|}
\hline \\
\hline Karakteristik Pasien & $\mathrm{n}(\%)$ \\
\hline Usia (tahun) & \\
\hline$<60$ Tahun & $43(55,1)$ \\
\hline$>60$ Tahun & $35(44,9)$ \\
\hline Jenis Kelamin & \\
\hline Laki-Laki & $57(73,1)$ \\
\hline Perempuan & $21(26,9)$ \\
\hline Penyakit Penyerta* & \\
\hline Asma & $36(31,6)$ \\
\hline Penyakit Paru Kronis & $26(22,8)$ \\
\hline Hipertensi & $14(12,3)$ \\
\hline Gagal Ginjal & $14(12,3)$ \\
\hline Diabetes Mellitus Tipe 2 & $15(13,1)$ \\
\hline Dispepsia & $4(3,5)$ \\
\hline Gagal Jantung & $4(3,5)$ \\
\hline Stroke & $1(0,9)$ \\
\hline Lama Rawat Inap & \\
\hline 1-3 Hari & $16(20,5)$ \\
\hline 4-7 Hari & $56(71,8)$ \\
\hline$>10$ Hari & $6(7,7)$ \\
\hline Gejala Klinis* & \\
\hline Sesak Nafas & $64(35,4)$ \\
\hline Batuk & $57(31,5)$ \\
\hline Demam & $48(26,5)$ \\
\hline Nyeri Ulu Hati & $12(6,6)$ \\
\hline sien dapat mengalami lebih & dari satu \\
\hline Asma merupakan & penyakit \\
\hline nyerta terbesar yang & banyak \\
\hline
\end{tabular}


$(31,6 \%)$. Selain itu juga pasien banyak memiliki riwayat penyakit paru kronis, hipertensi, gagal ginjal dan diabetes mellitus tipe 2 . Penelitian yang dilakukan oleh Suter-Widmer et al., (2012) menemukan bahwa penyakit paru kronis, gagal ginjal, diabetes dan gagal jantung signifikan $(\mathrm{p}<0,001)$ meningkatkan lama rawat inap di rumah sakit ${ }^{15}$. Oleh karena itu identifikasi terapi yang tepat pada penyakit penyerta dapat dilakukan agar pasien tidak terlalu lama dirawat di rumah sakit.

Gejala klinis yang banyak dikeluhkan oleh pasien pneumonia komuniti adalah sesak nafas $(35,4 \%)$, batuk $(31,5 \%)$, demam $(26,5 \%)$ dan nyeri ulu hati $(6,6 \%)$. Elshamly et al., (2016) juga menyebutkan bahwa pasien pneumonia komuniti dengan penyakit penyerta mengeluhkan panas $(85,7 \%)$, batuk (100\%) dan sesak nafas $(92,9 \%)$ saat mengalami pneumonia komuniti ${ }^{16}$.

Pola penggunaan antibiotika pasien pneumonia komuniti dapat dilihat pada gambar 1. Golongan beta-laktam merupakan golongan antibiotik yang paling banyak digunakan dalam bentuk intravena maupun oral dengan angka $62,0 \%$ dan $58,14 \%$ secara berturut-turut. Jenis golongan beta-laktam yang digunakan antara lain cefoperazone, cefotaxime dan ceftriaxone dalam bentuk IV dan cefixime dalam bentuk oral.

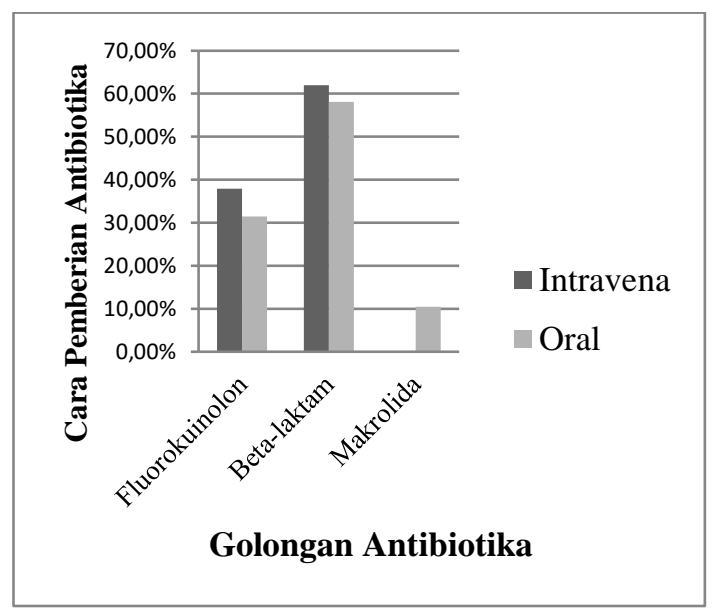

Gambar 1. Pola Penggunaan Antibiotika

Golongan fluorokuinolon merupakan antibiotik terbanyak kedua yang digunakan dalam bentuk intravena maupun oral dengan angka $38 \%$ dan $31,39 \%$ secara berturutturut. Jenis golongan fluorokuinolon yang digunakan antara lain levofloxacin dan moxifloxacin. Penelitian yang dilakukan oleh Shrayteh et al., (2014) di Libanon menemukan bahwa terdapat hubungan antara jumlah golongan 
antibiotika yang digunakan terhadap pola penggantian antibiotika dari IV ke oral. Pada penelitian tersebut golongan fluorokuinolon merupakan golongan yang paling banyak digunakan dengan angka 60,3\%. Golongan beta laktam juga digunakan untuk penggantian antibiotika dari IV ke oral sebesar $13,7 \%$. Kedua golongan tersebut banyak digunakan karena antibiotika tersebut memiliki formulasi dalam bentuk IV maupun oral ${ }^{17}$. Menurut IDSA tahun 2019 menyebutkan bahwa pasien pneumonia komuniti yang dirawat inap perlu diberikan terapi antiiotika golongan beta laktam, makrolida atau fluorokuinolon ${ }^{18}$. Penelitian ini menunjukkan bahwa pola penggunaan antibiotika pada pasien pneumonia komuniti di RSUD Wangaya telah sesuai dengan pedoman terapi. Hal tersebut sangat penting dilakukan untuk menurunkan kejadian resistensi pengobatan ${ }^{17}$.

Pasien pneumonia komuniti yang telah stabil perlu secepatnya dilakukan penggantian antibiotik IV menjadi oral. Penggantian antibiotika dari IV ke oral tentunya memiliki beberapa keuntungan yakni menurunkan biaya pengobatan, menurunkan risiko infeksi nosokomial dan menurunkan lama waktu rawat inap ${ }^{19}$. Tabel 2 menunjukkan bahwa 55 (70,5\%) pasien yang diteliti mengalami waktu penggantian antibiotik dalam 48-72 jam sejak dirawat inap.

Tabel 2. Penggantian IV ke Oral pasien Pneumonia Komuniti

\begin{tabular}{|c|c|}
\hline Penggantian IV ke Oral & $\mathrm{n}(\%)$ \\
\hline $\begin{array}{l}\text { Waktu Penggantian } \\
\text { Antibiotik } \\
48-72 \text { jam } \\
>72 \text { jam }\end{array}$ & $\begin{array}{l}55(70,5) \\
23(29.5)\end{array}$ \\
\hline $\begin{array}{l}\text { Pola Penggantian } \\
\text { Sequential } \\
\text { Switch Over } \\
\text { Step Down }\end{array}$ & $\begin{array}{l}21(27) \\
9(11,5) \\
48(61,5)\end{array}$ \\
\hline
\end{tabular}

Penelitian yang dilakukan oleh Shrayteh et al., (2014) juga menunjukkan bahwa pasien yang diberikan antibiotik dalam bentuk IV akan stabil pada hari ke 3,81 pengobatan sehingga perlu dilakukan penggantian antibiotik. Penelitian Mertz et al., (2009) juga menunjukkan hal yang serupa yakni waktu yang tepat untuk penggantian antibiotika dari IV ke oral adalah pada hari ke 2-4 pengobatan ${ }^{19}$. Penelitian ini menunjukkan bahwa praktik waktu penggantian antibiotik yang dilakukan di RSUD Wangaya 
telah tepat pada sebagian besar kasus.

Pola penggantian antibiotika IV ke oral pada pasien pneumonia komuniti dapat dilihat pada tabel 2 . Pola penggantian step down merupakan pola penggantian antibiotik yang paling banyak dilakukan dengan angka $48(61,5 \%)$ pasien. Hasil penelitian yang didapat tidak sejalan dengan penelitian yang dilakukan oleh Tejaswini et al., (2018) yakni pola penggantian sequential paling banyak digunakan untuk penggantian antibiotik dengan angka 58,53\%.

Antibiotik saat diberikan dalam bentuk sediaan IV secara langsung mencapai sirkulasi darah. Oleh karena itu bioavailabilitas sediaan IV adalah $100 \%^{20}$. Efektivitas sediaan IV yang diganti akan setara dengan sediaan oral apabila sediaan oral yang diganti bioekuivalen dan memiliki bioavailabilitas yang baik $(>80 \%)^{21}$. Pola penggantian step down merupakan pola penggantian antibiotika dari IV ke oral dengan kandungan yang berbeda dan potensi yang berbeda ${ }^{20}$. Pola penggantian step down yang banyak dilakukan di
RSUD Wangaya adalah dengan menggunakan golongan beta laktam yakni penggantian ceftriaxone atau cefoperazone IV menjadi cefixime oral. Ceftriaxone IV tidak memiliki sediaan oral yang ekivalen oleh karena itu pola penggantian yang dilakukan adalah step down ${ }^{21}$. Penggantian yang dilakukan adalah dengan cefixime oral yang memiliki biovailabilitas $<50 \%{ }^{22}$. Sehingga dapat dikatakan sulih terapi step down kurang ideal untuk mencapai target terapi yang diinginkan.

Pola penggantian sequential menempati urutan kedua dalam pola penggantian antibiotik dengan angka sebesar 21 (27\%). Pola penggantian sequential merupakan pola yang paling ideal untuk dilakukan agar mencapai target terapi yang diinginkan. Pola penggantian sequential yang banyak dilakukan di RSUD Wangaya adalah dengan menggunakan antibiotik golongan fluorokuinolon yakni penggantian levofloxacin IV menjadi levofloxacin oral. Levofloxacin oral memiliki biovailabilitas $>95 \%$. Sehingga dapat dikatakan sediaan oral yang diganti bioekuivalen dengan levofloxacin 
IV. Penelitian yang dilakukan Tejaswini et al., (2018) di India menyebutkan golongan fluorokuinolon banyak digunakan pada pola penggantian sequential karena golongan tersebut memiliki bentuk sediaan IV dan oral yang bioekuivalen dan mudah untuk diikuti. Selain itu juga pola penggantian sequential memiliki lama waktu penggantian IV ke oral yang lebih singkat dibandingkan step down yakni selama 3,95 hari dan 4,8 hari secara berturut-turut. Perbedaan waktu tersebut dapat mengakibatkan tingginya biaya pengobatan pada pola pengobatan step down ${ }^{21}$. RSUD Wangaya disarankan untuk lebih meningkatkan praktik pola penggantian sequential pada pasien pneumonia komuniti yang dirawat inap.

\section{KESIMPULAN}

Pola penggantian antibiotik dari IV ke oral yang paling banyak dilakukan di RSUD Wangaya adala step down sebesar 48 (61,5\%) kemudian dilanjutkan dengan sequential dan switch over dengan angka 21 (27\%) dan $9(11,5 \%)$ secara berturut-turut. RSUD Wangaya disarankan untuk lebih meningkatkan praktik pola penggantian sequential demi menurunkan beban biaya pengobatan pneumonia komuniti.

\section{UCAPAN TERIMA KASIH}

Terimakasih diucapkan kepada semua pihak yang telah membantu dan terlibat langsung dalam penelitian ini. Kepada semua civitas akademika Universitas Bali Internasional terima kasih telah memberikan sumbang saran, kritikan dan masukan agar sempurnanya penelitian ini. Peneliti juga menyampaikan ucapan terimakasih kepada RSUD Wangaya yang telah memberikan izin untuk dapat melakukan pengambilan data penelitian.

\section{DAFTAR PUSTAKA}

1. Brown JS, 2012, Communityacquired pneumonia,Clin Med J $R$ Coll Physicians London .12(6):538-43

2. Azmi S, Aljunid SM, Maimaiti N, Ali AA, Muhammad Nur A, De Rosas-Valera M, et al, 2016, Assessing the burden of pneumonia using administrative data from Malaysia, Indonesia, 
and the Philippines, Int $J$ Infect Dis. 49:87-93.

3. Patterson CM, Loebinger MR, 2012, Community acquired pneumonia: Assessment and treatment, Journal of the Royal College of Physicians of London. 12: 283-6.

4. Aliberti S, Blasi F, Zanaboni AM, Peyrani P, Tarsia P, Gaito $S$, et al, 2010, Duration of antibiotic therapy in hospitalised patients with communityacquired pneumonia, Eur Respir J. 36(1):128-34.

5. Cunha BA, 2001, Oral or intravenous-to-oral antibiotic switch therapy for treating patients with communityacquired pneumonia. American Journal of Medicine. 111: 4123.

6. Engel MF, Postma DF, Hulscher MEJL, Van Berkhout FT, Emmelot-Vonk MH, Sankatsing $\mathrm{S}$, et al, 2013, Barriers to an early switch from intravenous to oral antibiotic therapy in hospitalised patients with CAP, Eur Respir J. 41(1):123-30

7. Berha AB, Kassie GM, 2019, Current practice and barriers to an early antimicrobial conversion from intravenous to oral among hospitalized patients at jimma university specialized hospital: Prospective observational study, Interdiscip Perspect Infect Dis.

8. Ramirez JA, Cooper AC, Wiemken $\mathrm{T}$, Gardiner D, Babinchak T, 2012, Switch therapy in hospitalized patients with community-acquired pneumonia: Tigecycline vs. Levofloxacin, BMC Infect Dis.
12:159.

9. Schouten JA, Hulscher MEJL, Trap-Liefers J, Akkermans RP, Kullberg BJ, Grol RPTM, et al, 2007, Tailored interventions to improve antibiotic use for lower respiratory tract infections in hospitals: A cluster-randomized, controlled trial, Clin Infect Dis. 44(7):931-41.

10. Kuper KM, 2020, Intravenous to Oral Therapy Conversion, Competence Assess Tools Heal Pharm. 351-62.

11. Glemaud I, 2000, Use of a physician order entry system to identify opportunities for intravenous to oral levofloxacin conversion, American Journal of Health-System Pharmacy

12. Hunter KA, Dormaier GK, 1995 , Pharmacist-managed

intravenous to oral step-down program, Clin Ther. 17(3):53440.

13. Mettler J, Simcock M, Sendi P, Widmer AF, Bingisser R, Battegay M, et al, 2007, Empirical use of antibiotics and adjustment of empirical antibiotic therapies in a university hospital: A prospective observational study, BMC Infect Dis. 7:21.

14. Menéndez R, Ferrando D, Vallés JM, Martínez E, Perpiñá M, 2001, Initial risk class and length of hospital stay in community-acquired pneumonia, Eur Respir J. 18(1).

15. Suter-Widmer I, Christ-Crain M, Zimmerli W, Albrich W, Mueller B, Schuetz P, et al, 2012, Predictors for length of hospital stay in patients with community-acquired 
Pneumonia: Results from a Swiss Multicenter study, BMC Pulm Med. 12(1):21.

16. Elshamly M, Nour MO, Omar AMM. 2016. Clinical presentations and outcome of severe community-acquired pneumonia, Egypt J Chest Dis Tuberc. 65(4):831-9.

17. Shrayteh ZM, Rahal MK, Malaeb DN, 2014, Practice of switch from intravenous to oral antibiotics, Springerplus. 3(1):717.

18. Metlay JP, Waterer GW, Long AC, Anzueto A, Brozek J, Crothers K, et al, 2019, Diagnosis and treatment of adults with community-acquired pneumonia, Am J Respir Crit Care Med. 200(7):45-67.

19. Mertz D, Koller M, Haller P, Lampert ML, Plagge H, Hug B, et al, 2009, Outcomes of early switching from intravenous to oral antibiotics on medical wards, J Antimicrob Chemother. 64(1):188-99.

20. Cyriac JM, James E, 2014, Switch over from intravenous to oral therapy: A concise overview, Journal of Pharmacology and Pharmacotherapeutics, 5: 83-7.

21. Tejaswini YS, Challa SR, Nalla KS, Gadde RS, Pavani AL, Neerisha V, 2018, Practice of Intravenous to Oral Conversion of Antibiotics and its Influence on Length of Stay at a Tertiary Care Hospital: A Prospective Study, $J$ Clin DIAGNOSTIC Res. 12(3):1-4

22. Wetzstein GA, 2000, Intravenous to oral (IV:PO) antiinfective conversion therapy. Cancer Control. 7(2):170-6. 